Journal of Engineering Science and Technology Review 5 (4) (2012) 48 -55

Special Issue on Renewable Energy Systems
JOURNAL OF

Engineering Science and

Technology Review

Research Article

www.jestr.org

\title{
Biogas Systems: Basics, Biogas Multifunction, Principle of Fermentation and Hybrid Application with a Solar Tower for the Treatment of Waste Animal Manure
}

\author{
S. Alexopoulos \\ Solar-Institut Jülich (SIJ), FH Aachen, Aachen University of Applied Sciences, Germany
}

Received 22 August 2012; Revised 30 September 2012; Accepted 10 October 2012

\begin{abstract}
Two of the main environmental problems of today's society are the continuously increasing production of organic wastes as well as the increase of carbon dioxide in the atmosphere and the related green house effect. A way to solve these problems is the production of biogas. Biogas is a combustible gas consisting of methane, carbon dioxide and small amounts of other gases and trace elements. Production of biogas through anaerobic digestion of animal manure and slurries as well as of a wide range of digestible organic wastes and agricultural residues, converts these substrates into electricity and heat and offers a natural fertiliser for agriculture. The microbiological process of decomposition of organic matter, in the absence of oxygen takes place in reactors, called digesters. Biogas can be used as a fuel in a gas turbine or burner and can be used in a hybrid solar tower system offering a solution for waste treatment of agricultural and animal residues. A solar tower system consists of a heliostat field, which concentrates direct solar irradiation on an open volumetric central receiver. The receiver heats up ambient air to temperatures of around $700^{\circ} \mathrm{C}$. The hot air's heat energy is transferred to a steam Rankine cycle in a heat recovery steam generator (HRSG). The steam drives a steam turbine, which in turn drives a generator for producing electricity. In order to increase the operational hours of a solar tower power plant, a heat storage system and/ or hybridization may be considered. The advantage of solar-fossil hybrid power plants, compared to solar-only systems, lies in low additional investment costs due to an adaptable solar share and reduced technical and economical risks. On sunny days the hybrid system operates in a solar-only mode with the central receiver and on cloudy days and at night with the gas turbine only. As an alternative to methane gas, environmentally neutral biogas can be used for operating the gas turbine. Hence, the hybrid system is operated to $100 \%$ from renewable energy sources
\end{abstract}

Keywords: : biogas, waste manure, fermentation, solar tower, hybridization

\section{Introduction}

Biogas covers a wide and difficult to manage range, starting from forest and farming wastes (including fermented liquid manure) through sewage sludge to municipal wastes. Its field of application includes combustion engines, burners as well as gas turbines for electricity generation and cogeneration of heat and power. Biogas can be further enhanced from low-quality to natural gas quality before it is fed in the public gas grid. Biogas can be gained in an anaerobic digestion process from different organic substances, e.g. from energy crops, agricultural waste or municipal organic waste. It is produced from organic wastes by concerned action of various groups of anaerobic bacteria through anaerobic decomposition. Different parameters have a direct influence to the fermentation process. Biogas is a renewable source of energy. The carbon dioxide that is

*E-mail address: alexopoulos@sii.fh-aachen.de ISSN: 1791-2377 @ 2012 Kavala Institute of Technology. All rights reserved. released when biogas is combusted and mixed with the oxygen in the air does not contribute to the greenhouse effect, since the carbon in the biogas is already in the biosphere circulation above the earth's crust. The same amount of carbon dioxide would be released if the biological material was allowed to decompose instead. The carbon in the methane molecule produced by the biogas process originates from the carbon dioxide in the air that the plants have taken up by photosynthesis. Natural gas was also produced in this way, but the carbon in natural gas has been stored in the earth's crust during millions of years and is therefore not carbon dioxide neutral when it is extracted from these fossil layers within the earth. Thus, compared with natural gas, biogas has significant benefits for the environment [1]. Table 1 shows its composition.

Table 1: Biogas composition

\begin{tabular}{c|c|c}
\hline Component & Symbol & Concentration \\
\hline Methane & $\mathrm{CH} 4$ & $50-75$ Vol.-\% \\
Carbon dioxide & $\mathrm{CO} 2$ & $25-45$ Vol.-\% \\
\hline
\end{tabular}




\begin{tabular}{c|c|c}
\hline Water vapor & $\mathrm{H} 2 \mathrm{O}$ & $2-7$ Vol.-\% \\
Oxygen & $\mathrm{O} 2$ & $<2$ Vol.-\% \\
Nitrogen & $\mathrm{N} 2$ & $<2$ Vol.-\% \\
Ammonia & $\mathrm{NH} 3$ & $<1$ Vol.-\% \\
Hydrogen & $\mathrm{H} 2$ & $<1$ Vol.-\% \\
Sulfide & $\mathrm{H} 2 \mathrm{~S}$ & $20-20.000 \mathrm{ppm}$ \\
\hline
\end{tabular}

Regardless of the substrate, it has two major components: methane and carbon dioxide. Biogas is composed of $45-85 \%$ methane and $15-45 \%$ carbon dioxide, depending on the conditions during production. Moreover, biogas comprises small amounts of hydrogen sulphide, ammonia and nitrogen.

One important cycle necessary to understand the biogas is the cycle of matter, which is shown in Fig. 1. From the production of feedstock to the application of digestate as fertiliser, the biogas provides a closed nutrient and carbon cycle. Carbon dioxide $\left(\mathrm{CO}_{2}\right)$ is re-uptaken by vegetation during photosynthesis [2]. Plants are consumed by animals as food. Much of the carbon consumed by them ends up in manure. If not consumed by animals, plants e.g. trees may burn in a fire and release $\mathrm{CO}_{2}$ or might become to organic material after the life cycle of them has finished. If plants are burned in fire it will take another 20 to 50 years for carbon to be taken out of atmosphere and only if enough trees are planted.

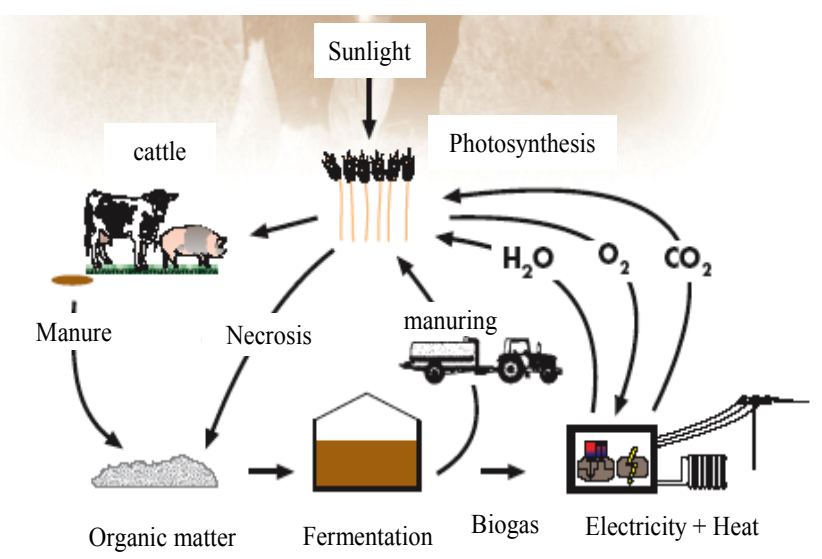

Fig. 1: Cycle of matter

Food wastes from meat or plant sources are decaying to organic material and for the whole cycle of matter it is necessary to consider that animal and plant respiration also produces $\mathrm{CO}_{2}$ If the manure and/or the organic matter are used in a fermenter then by this process biogas is build and stored. By burning biogas electricity and heat is produced. Further products are exhausted gases like water and $\mathrm{CO}_{2}$. The carbon dioxide is then selected by the plants for photosynthesis and the cycle of matter for carbon is closed. Some carbon compounds remain in the digestate, improving the carbon content of soils, when digestate is applied as fertilizer [2].

\section{Biogas potential}

A world estimation for 2020 comes to a total installed capacity of $15,000 \mathrm{MW}$ avoiding $60 \mathrm{Mio}$. tons of $\mathrm{CO}_{2}$ per year. Biogas sources vary distinctively among the members of the European Union. Germany, Austria and Denmark produce the largest share of their biogas in agricultural plants using energy crops, agricultural by products and manure, whereas the UK, Italy, France and Spain predominantly use landfill gas. This source might not increase further in the medium and longer term as the EU directive on landfill waste foresees a gradual reduction of the land filling of biodegradable municipal waste (by 2016 to 35 $\%$ of the level in 1995) [3]. Theoretic potential of primary energy production from biogas is 166 Mtoe in 2020, according to a German study.This potential of 500 TWh (43 Mtoe) for the 500 million people living in the EU27 is derived from agricultural byproducts and waste alone (organic waste from households and industries, sewage sludge, manure, catch crops, landscape cleaning).The realistic potential of methane derived from animal manure and energy crops and waste lies in the range of 40 Mtoe in 2020 as compared to a production of 5.9 Mtoe in 2007. The useof catch crops for biogas production was not considered in the calculation and offers an additional potential. In 2020 biogas could deliver more than a third of Europe's natural gas production or around $10 \%$ of the European consumption (433.7 Mtoe in 2007) Within the overall potential of biomass for energy in Europe biogas could reach $15 \%$ to $25 \%$ of total bio energy, as compared to $7 \%$ in 2007 [3].

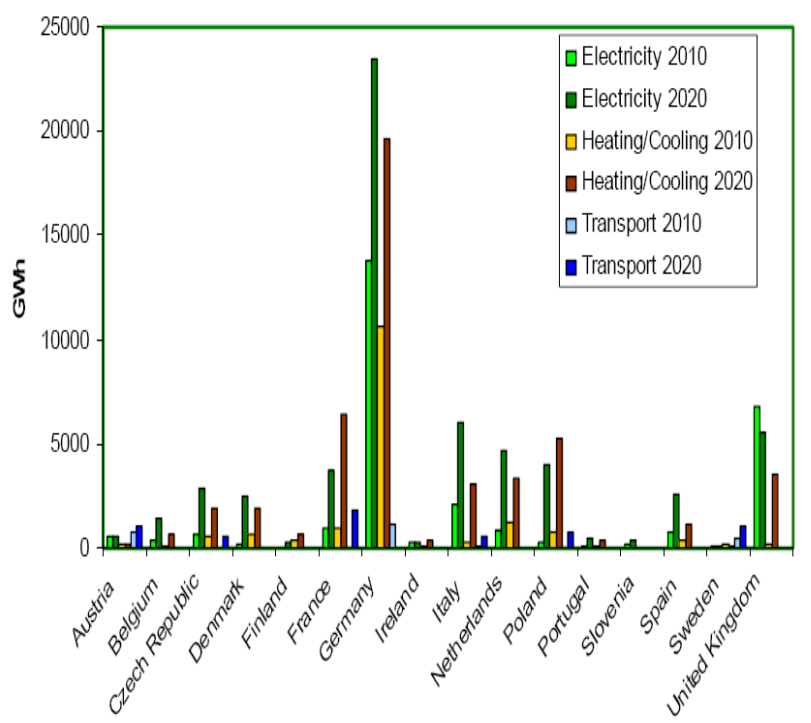

Fig. 2: Biogas from 2010 -2020 Source: EU

Many European countries have established favourable conditions for electricity production from biogas. Germany has a leading role in Europe with almost 4000 biogas plants, most of them on farms for cogeneration. Total energy potential of biogas in Germany is $752 \mathrm{PJ}$ and more than 9,500 MW, are installed which make about $20 \%$ of electricity production. Fig.3 shows the installed electric power and number of biogas plants in the last two decades in Germany. A steady growing trend of both characteristic numbers characterizes the development. The German Institute for Energy and Environment states that the biogas potential in Europe is as high enough to be feasible to replace the total consumption of natural gas, by injection of upgraded biogas (biomethane) into the existing natural gas grid [2]. 


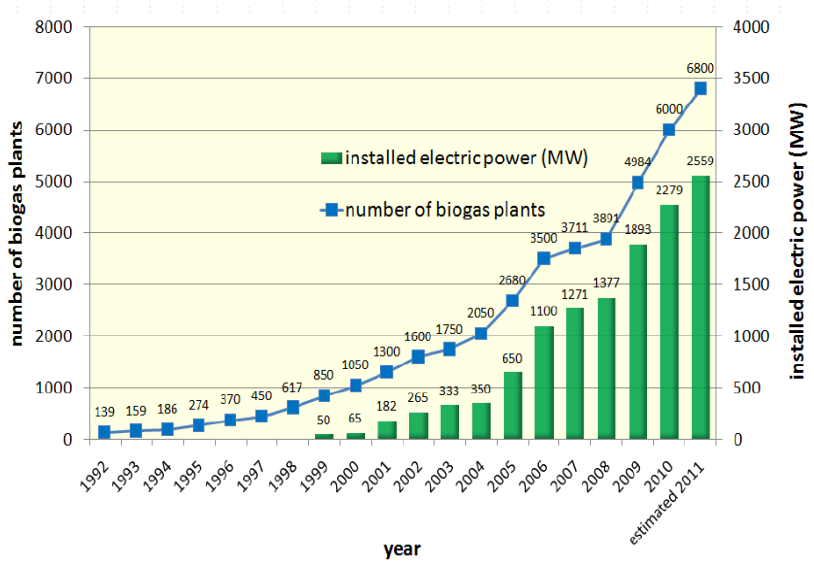

Fig.3: Installed electric power and number of biogas plants in Germany, (Source: German Biogas Association)

Austria, a further country with biogas development in Europe has 294 biogas plants producing green electricity in 2008. The average size of $260 \mathrm{kWe}$ installed power shows the decentralized structure of biogas [3]. For Italy, the best biogas performance is recorded in the northern part of the country especially in the regions of Lombardy, Emilia Romagna, Trentino A.A, Veneto and Piedmont. With a share of $23.8 \%$, the region of Lombardy is the biggest producer of biogas in Italy and dominates the biogas market. Moreover, Lombardy has the biggest biogas potential, which is estimated at 4,643 GW. As for the production of biogas from manure, 3,800,000 pigs and 1,600,000 heads of cattle were counted for the region of Lombardy in the ISTAT census in 2001. Together this amounts to $44 \%$ of the total domestic animal breed in Italy [4].Taking Sweden as an example from Scandinavia, the country has approximately 233 biogas facilities with a total biogas production of $1.3 \mathrm{TWh} / \mathrm{a}$ [5]. Biogas can be produced at large-scale centralized plants, where different feed stocks materials are digested, and at small farm-based plants, which use and digest mainly agricultural feed stocks. The theoretical potential of biogas production in Sweden lies at around 14-17 TWh/a, which is more than 10 times that of the present annual production [6]. From the feed stocks materials $70 \%$ is manure and farm waste, $13 \%$ is industrial waste, $9 \%$ is household waste and the remainder is garden waste and sewage sludge. Another important application of biogas is as vehicle fuel. The market for biogas as vehicle fuels has been growing rapidly in recent years for example in Sweden. 2008 there were 17,000 vehicles driving on upgraded biogas/ natural gas. There are currently 38 upgrading plants and in 2008 about $25 \%$ of Sweden's biogas production was used as vehicle fuel and $60 \%$ of the total gas volume sold as vehicle fuel was biogas and only $40 \%$ consisted of natural gas [3].

\section{Scheme of a biogas plant}

A general scheme of a biogas plant is described in detail in Fig. 4. Manure and/or biomass like energy corps or bio waste from houses are inserted in a receptor tank. These materials are running before a pre-treatment process mixing, macerating, hygienisation/ sterilisation and other pretreatment step like concentration. A pump delivers the fluid mixture to a reactor. In general the resulting feedstock is available in close proximity to the plants (manure, maize, grass) and transportation costs are kept to a minimum. The insulated reactor is heated up to $35^{\circ}$ or $55^{\circ} \mathrm{C}$ in order to achieve ideal temperature conditions for the bacteria which produce methane. A mechanic or hydraulic stirring device provides a homogenous temperature distribution and supplies bacteria uniformly with nutrients inside the fermenter. Fermenters are divided in different types: plug flow reactor, complete stirring reactor, fermenter with foil and huge fermenter with central stirring device. Selection of the appropriate type of digester is oriented primary on the dry mass content of the fermentation material. As construction material for the fermenters black steel, sheet steel, stainless steel or beton can be applied.The produced biogas is fed to a gas storage tank. A condensate separator filters particles and selects condensate water. The biogas produced may be upgraded with a chemical treatment further to natural gas and inserted to the gas net. Another application is the direct firing in a co-generation unit. A gas engine produces electricity with a generator and the produced heat can be used as process heat for households or for the heating of the fermenter. Manure end product is selected to a storage tank. First the gas is separated from the sludge which is fed to a decanter in order to separate the solid material from the remaining fluid.

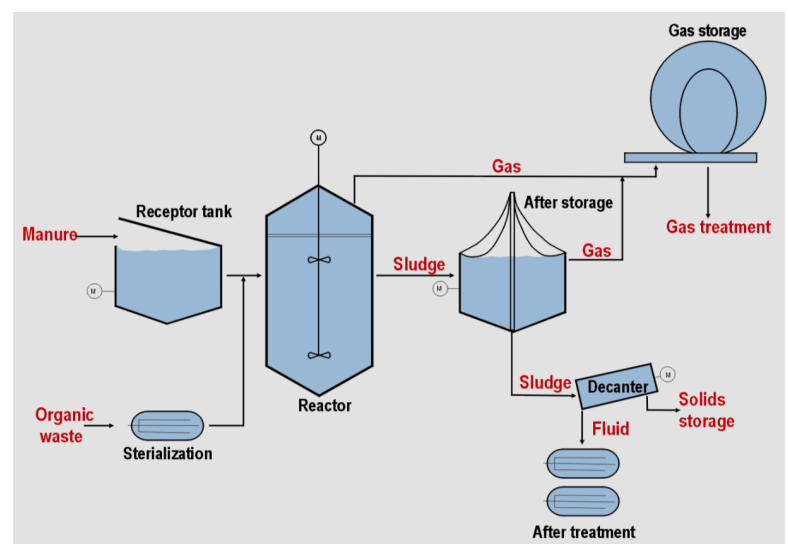

Fig. 4: Scheme of a biogas plant

Fig. 5 shows a scheme of a dom biogas plant for developing countries. Such systems are very simple and can be installed with low cost. For nearly a century biogas technologies in developed and developing countries are installed and in operation. Mainly agricultural households produce biogas on the basis of organic residual, waste materials and animal manure. The majority of the installed plants has a nominal volume of $10 \mathrm{~m}^{3}$ for the fermenter and provides around 1.5 to $4 \mathrm{~m}^{3}$ biogas per day [7].

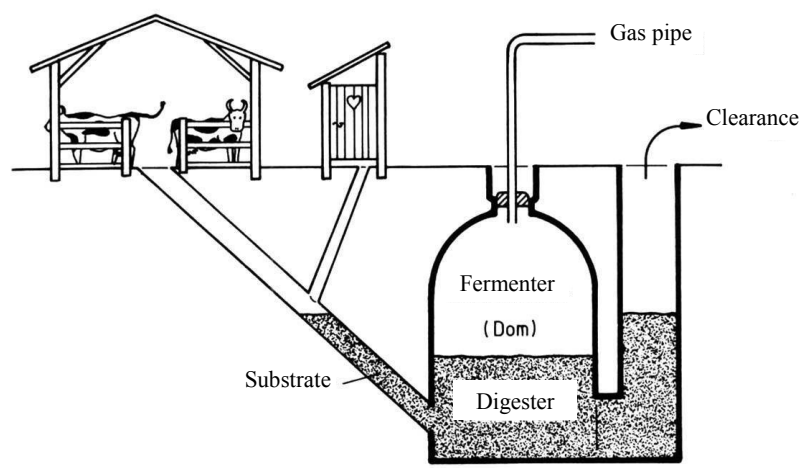

Fig. 5: Dom biogas plant for developing countries 
In India alone, there are over 250 million cattle and if one third of the manure produced annually from these is available for production of biogas, more than 12 million biogas plants can be installed which have the estimated biogas potential capacity of 17,000 MW. Biogas technology provides an alternate source of energy in rural India, and is an appropriate technology that meets the basic need for cooking fuel in rural areas by using local resources, cattle waste and other organic wastes [8].

\section{Principle of fermentation}

The principle of fermentation is shown in Fig. 6. As depicted in [9] bacteria of particular phases are closely interdependent and influence each other: methane is produced as quickly and much as digestible material is provided.

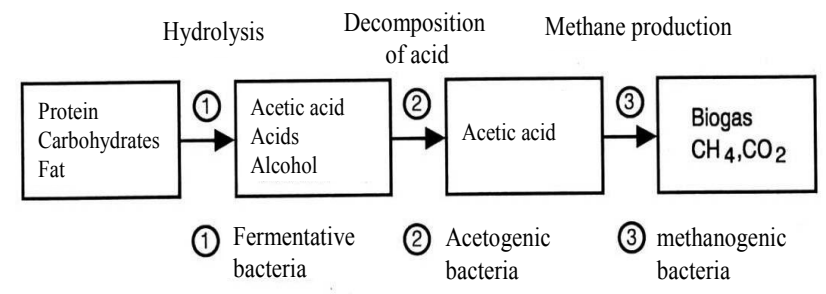

Fig. 6: Principle of fermentation

In the first step complicated molecules like polymers, fat, proteins and carbohydrates are converted to monomers, fatty acids, amino acids and saccharids. During this time only fermentative bacteria are active and the process is called hydrolysis. Intermediate resulting products are acetic acid $\mathrm{CH}_{3} \mathrm{COOH}$, alcohol, water, hydrogen, $\mathrm{CO}_{2}$ and $\mathrm{NH}_{4}$.

In the second stage, acetogenic bacteria dismantle the remaining complex organic molecules like alcohol into acetic acid. The acetic acid is the end product of this decomposition of actid. When acetic acid has been produced in sufficient quantities, a further type of bacteria starts to convert it into methane. This last step is called methane production and the bacteria involved are called methanogenic bacteria. The decomposed carbon is converted almost completely into methane. End product of fermentation is the combustible biogas.

\section{Impact parameters}

For biogas plants organic residues are introduced into a septic tank and subjected to temperatures of $35^{\circ} \mathrm{C}$ in a fermentation process. The heating to the required reaction temperature is obtained by partial combustion of the product gas. The recovered gas is purified, buffered and finally delivered to the consumer. The solid residue is used as fertiliser.Methane producing bacteria are particularly influenced by ambient conditions, which can slow or halt the process completely. The potential gas production is highly dependent on the nature of the organic substance and the process conditions of temperature and residence time.The reactions and thus gas production, and gas composition residues are influenced by the aqueous feedstock. Sulfurcontaining biomass produced naturally much $\mathrm{H}_{2} \mathrm{~S}$. Lignin is microbially degraded only slowly, so that lignin-containing materials results in low gas yield and long digestion times [10]. The methane bacteria are strictly anaerobic. If still oxygen is in the substrate then it must be consumed by anaerobic bacteria. Moisture and anaerobic conditions as well as organic uniform waste (biomass) charging e.g. sewage, wood pulp is essential for the digester process. A fermenter, supplied with bacteria (methanogens and decomposers) should have a digester volume of more than $100 \mathrm{~m}^{3}$. The energy content of the biogas is directly dependent on the methane content. The higher the content of substances such as fats and starch that is easy to break down in the fermented mass, the greater the gas yield.

Table 2 shows the composition of pig, cow and chicken manure. Highest composition is carbohydrates for pig manure and crude fiber for cow manure. Chicken manure has similar high composition of carbohydrates, protein and ash.

Table 2: Composition of different manure materials

\begin{tabular}{|c|c|c|c|}
\hline & \multicolumn{2}{|c|}{ Pig manure Cow } & \multirow{2}{*}{$\begin{array}{l}\text { Chicken } \\
\text { manure [\%] }\end{array}$} \\
\hline & {$[\%]$} & $\begin{array}{l}\text { manure } \\
{[\%]}\end{array}$ & \\
\hline Carbohydrates & 38 & 20 & 25 \\
\hline Fat & 4 & 4 & 4 \\
\hline Protein & 19 & 15 & 29 \\
\hline Crude fiber & 20 & 40 & 15 \\
\hline Ash & 19 & 21 & 27 \\
\hline
\end{tabular}

The substrate form must be degradable, should be available at a constant mass/volume flow and should have a nearly constant composition. To avoid high loading of the fermenter, a continuous feeding in shortest possible time intervals is favorable. Concentration of organic dry matter should be higher than $2 \%$ and it should be liquid slurry. Methane bacteria can increase their population and can only continue with the production of biogas if the substrate is suspended in sufficient water. In contrast to aerobic bacteria, yeasts and fungi, they can not exist in the solid phase [11]. Ideal dry substance concentration is $3 \%-10 \%$. Methane bacteria can not degrade fats, proteins, carbohydrates and cellulose in pure form. Rather, they need to build their cell substance soluble nitrogen compounds, minerals and trace elements.The non-organic substances dissolved in water must be either granted or finely structured so that a large surface is formed. Materials such as straw, long grass or shredded vegetables, and organic waste as possible frayed, otherwise required to have long digestion time and problems of swimming layers occur [11].Optimum $\mathrm{pH}$-value in the fermentation is 6.5-7.2. In slurry and manure, this area is through the formation of ammonium usually occurs spontaneously. Anaerobic bacteria, specially the methanogens, are sensitive to the acid concentration within the digester and their growth can be inhibited by acidic conditions. With acidic substrates such as mash, and whey silage may need to decorate that lime to raise the value. Moreover, it is also sensitive to high oxygen concentrations [12].As digestion reaches the methanogenesis stage, the concentration of ammonia increases and the $\mathrm{pH}$ value can increase to above 8 . Once $\mathrm{CH}_{4}$ production is stabilized, the $\mathrm{pH}$ level stays between 7.2 and 8.2 [13]. Substrate shall not include substances with antibacterial impact like heavy metals, mediums for the disinfection of stables and 
antibiotics for the animals. Light is not fatal, but inhibits the process. The process of biogas production takes place in anaerobic conditions and in different temperature diapasons. There are psychrophilic (temperature diapason $10-25^{\circ} \mathrm{C}$ ), mesophilic $\left(25-40^{\circ} \mathrm{C}\right)$ and thermophilic $\left(50-55^{\circ} \mathrm{C}\right)$ regimes of bioconversion. Biogas production in a thermophilic regime is much higher than for the mesophilic and psychrophilic regimes. Modern thermophilic bioreactors can produce 2-6 $\mathrm{m}^{3}$ per $\mathrm{m}^{3}$ of installation, which amounts to 5-15 $\mathrm{kg}$ of waste on a dry mass base (or $50-150 \mathrm{~kg}$ of wet mass). For mesophilic biogas installations, these values are 0.2-0.4 $\mathrm{m}^{3}$ per $\mathrm{m}^{3}$ of installation and $0.5-1 \mathrm{~kg}$ on a dry mass base (or $5-10 \mathrm{~kg}$ of wet mass). The higher the temperature, the bacteria are more sensitive to temperature fluctuations, especially if these occur in the short term and the temperature drops.Organic material is treated in the reactor for a certain period of time. The average time allowed for digestion of the material in the reactor before it is removed is called the retention or residence time. This varies depending on the properties of the substrate and on how much methane can be extracted. The retention time is sometimes expressed as the hydraulic retention time (HRT), which normally varies between 10 and 40 days. The shortest retention times are usually found at sewage treatment plants, whereas codigesters often require longer retention times [1].The speed of the digestion process is very strongly temperature dependent. The higher the temperature, the faster the degradation and the higher the gas production, the shorter the digestion time and the lower the methane content in biogas. Mesophile bacteria have a digestion time of 20-25 days and thermophile bacteria of 3-10 days. The retention time varies for different materials. For wheat, haulm and corn it takes high values of 78, 53 and 52 respectively. For other substances like clover and grass it takes lower values of 28 and 25 respectively. Sugar beet has very small residence time of only 14 days.One further characteristic parameter is the C:N:P:S-ratio, the ratio of the different elements of each material used for the production of biogas. Fig. 7 shows the C:H:N:P:S:Ash ratio for different materials which are used for fermentation.

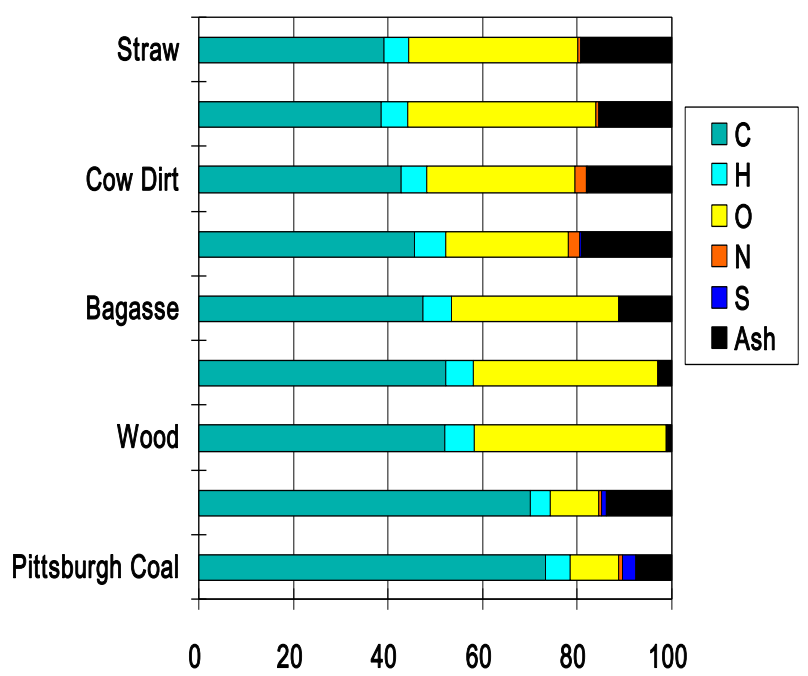

Fig. 7: C:H:N:P:S:Ash ratio for different materials

For example the ratio for $\mathrm{C}: \mathrm{N}: \mathrm{P}: \mathrm{S}$ is for cattle manure $600: 40: 2: 4$, for corn $600: 20: 4: 2$, for grass $600: 17: 4: 2$ and for crop $600: 7: 2: 11$. Recommended is a ratio for $C: N: P: S$ of:
$600: 15: 5: 3$. Regarding this optimum ratio and the retention time a substrate with $70 \%$ manure $30 \%$ biomass is ideal.

\section{Multifunction of biogas}

Biogas has a multifunction with a variety of different positive effects.One main advantage is the use for power and heat production as well as fuel. The biogas provides highquality energy in the form of electricity, heat and power to drive motors. The energy production comes to the aspect of promoting renewable energies, particularly of great importance. The produced biogas can be combusted in a gas turbine or a gas engine which generates electricity and heat. A micro gas turbine represents a new alternative to motordriven gas utilisation that produces gas turbine and heat. Micro gas turbines or micro turbines are small, fast-running gas turbines with low temperatures and pressures in the combustion chamber and an electrical capacity up to 200 $\mathrm{kW}$. Impurities in the bio-gas can damage the micro turbine, therefore the gas must be cleaned and dried. Micro gas turbines require a minimum methane content of $35 \%$ in the gas. The electrical efficiency is relatively low at about $28 \%$. The overall degree of efficiency is about $82 \%$. As there is continuous combustion with excess air and at low pressures in the combustion chamber, micro gas turbines have considerably lower exhaust emissions than engines. The intervals between maintenance are, at least in the case of micro gas turbines that run on natural gas, far longer than for engines [14].Biogas can be used to produce both power and heat in the same plant. About $30-40 \%$ of the energy can be extracted as electricity and the remainder as heat. As in the case when only heat is produced, the gas must be dried before combustion [1].Produced during the anaerobic digestion biogas can implement the use of heat / power cogeneration and heat into electricity or conversion to natural gas quality and feeding into the gas grid. Upgraded biogas can replace natural gas, since it can be used in the same way.Its upgrading has gained increased attention due to rising oil and natural gas prices and increasing targets for renewable fuel quotes in many countries. New plants are continually being built. The number of upgrading plants was around 100 in 2009 [15]. The process of upgrading biogas generates new possibilities for its use since it can then replace natural gas. Biogas produced is refined in several process steps to meet natural gas standards. The necessary purification process includes desulphurisation, drying and the separation of $\mathrm{CO}_{2}$. The high proportion of methane and the low levels of nitrogen, oxygen and hydrogen sulphide are characteristic for the quality of natural gas. Hydrogen sulphide is into sulphate and then discharges it. The system is designed to reduce the concentration of the incoming biogas from $2000 \mathrm{ppm}$ down to a maximum of $200 \mathrm{ppm}$. Further the biogas is analysed and enters a $\mathrm{CO}_{2}$-separation and drying stage. Carbon dioxide is adsorbed by an adsorption material like for example activated carbon. Methane leaves the plant with a methane concentration of 97 $\%$ and is injected into the gas grid.After been upgraded to methane it can be used in natural gas grids and be fed into the gas distribution net or filling stations. Biogas is the most environmentally-friendly vehicle fuel on the market today, and can also be used as a raw material in industry. Biomethane may be used in different forms of vehicles with spark and compression ignition engines which are designed to run on combination of diesel and methane. Biogas has many advantages as the replacement of petrol and diesel. 
Biogas gives the smallest emissions of carbon dioxide and particulate matter of all vehicle fuels on the market today. The methane molecule is the simplest of all hydrocarbons, which means that the exhaust produced by combustion is very clean. Biogas-powered vehicles have excellent exhaust values, which are only about half as high as the gasoline in accordance with EEC driving test. In addition, the $\mathrm{CO}_{2}$ emissions originate from non-fossil source, which does not lead to an increase of the greenhouse effect.The most important contribution of biogas technology to environmental protection is that it avoids additional carbon dioxide $\left(\mathrm{CO}_{2}\right)$ emissions compared with fossil energy sources. Producing energy from biogas is largely $\mathrm{CO}_{2}$ neutral, i.e. the $\mathrm{CO}_{2}$ released by burning biogas was previously removed from the atmosphere during the generation of biomass through photosynthesis [14].The application of digestate, as well as of raw manure and waste products as fertiliser, may pose health risks for animals and humans. For this reason, the use of digestate as fertiliser is usually governed by regulations and standards that protect animal and human health as well as the quality of crops. The biogas process has many advantages from the point of view of the environment, especially since it results in two environmentally-friendly final products, biogas and an organic residue, which is sometimes called bio-manure. Biomanure is a valuable fertilizer, which when returned to soil, results in a recycling of nutrients between urban and rural areas. Anaerobic digestion in a biogas plant is very effective at lowering the pathogen load in the digestate and save mineral manure. As mentioned in [16] it can offer a useful means of reducing numbers of pathogens that could otherwise lower the productivity of livestock farms or present a risk to human health. Farms with a mesophilic digester would benefit from a significant or total destruction of many disease-spreading spores that can affect their crops.

Methane emissions can be avoided by digesting the manure in closed chambers (reactors) where all the methane is collected as biogas for later combustion. The resulting digestate still contains all the necessary nutrients for plant growth. It is a valuable soil fertiliser, rich in nitrogen, phosphorus, potassium and micronutrients, which can be applied on soils with the usual equipment for application of liquid manure. Compared to raw animal manure, digestate has improved fertiliser efficiency due to higher homogeneity and nutrient availability and better $\mathrm{C} / \mathrm{N}$ ratio [2]. The remaining, poorly degradable carbon compounds are essential for the formation of humus, which is otherwise lost due to modern farming on a large scale. It therefore contributes in the closing of natural cycles and reduces the very polluting production of artificial fertilizers and environmentally damaging imports of peat as a soil conditioner. Further biogas production helps to protects water resources. Anaerobic digestion produces an effective and easily handled nitrogen fertilizer which can be incorporated in soil in precise amounts. Nitrogen losses and environmental impacts due to ammonia and nitrous oxide emissions are also minimized because plants can quickly extract the nutrients from the digested manure. The leaching of water-soluble nitrate is also reduced, which decreases the risk of nitrogen leaching to groundwater and surface waters.

Anaerobic digestion may have also positive effect on fly control. Problems caused by odours are sometimes experienced at biogas plants, usually in connection with waste deliveries prior to digestion. New technologies are being developed to address these problems. For example, some plants have installed compost filters that reduce odours during handling and pasteurization of fresh wastes.Animal manures and many organic wastes contain volatile organic compounds that can produce unpleasant odours. [17] showed that digestion significantly reduced concentrations of many of these compounds, such that their potential for giving rise to offensive and lingering odours during storage and spreading was significantly reduced. The reduction in the number of viable weed seeds in digestate will lower their dispersal by land spreading and as a consequence there will be less need for herbicides. Mesophilic anaerobic digestion can reduce the viability of the weed seeds and also of some crop seeds [16].Finally installation of biogas plants may cause a strong industrial growth with many companies working in this field.

\section{Hybrid application with a solar tower for the treatment of waste animal manure}

Through the whole world different biomass and biogas plants are in operation. In Europe a variety of different biogas plants have been constructed and are mainly producing power and heat.Hybridization of biomass with CSP is mentioned in different papers. [18] evaluates and compares several options for solar power towers, parabolic troughs and Fresnel lenses using direct steam, heat transfer fluid and compressed air as working fluids with combined cycles. Mainly hybridization of Fresnel collectors with biomass [19] or of parabolic trough collectors with biomass [20] are considered in these studies. Most of these hybridization proposals use a rankine cycle. The Biomasol Pilot Plant combines a trough collector solar field with a particular combination of biomass boilers to feed a $2 \mathrm{MWel}$ Rankine cycle, resulting in a hybrid power plant that empowers both technologies main advantages [21]. Another possible application is the integration of a biogas plant to a solar thermal power block of a solar tower. Germany's first solar tower power plant (STJ), which has a rated power output of $1.5 \mathrm{MW}_{\mathrm{e}}$, was constructed and completed in 2008 in the town of Jülich [22]. It commenced solar operation in spring of 2009. At the STJ, the heliostat field, a field of suntracking mirrors, reflects and concentrates the direct solar irradiation onto the open volumetric receiver. Incident sun rays enter the receiver, are absorbed inside and heat it up. To remove the heat, ambient air is continuously sucked through and is heated up to almost $700^{\circ} \mathrm{C}$. The hot air is passed through a heat recovery steam generator (HRSG) in which it passes its heat to a water-steam cycle. The produced steam is expanded in a steam turbine and the rotation of the turbine's shaft drives a generator to produce electricity. This system concept offers several benefits. Air as heat transfer medium is available for free, non-toxic and does not require freeze protection during times of non-operation. Operation with steam parameters as customary in conventional power plant engineering ensures high efficiency and optimum use of the available solar energy. Major parts of the plant can be built by using standard components from conventional power plant construction [23]. The advantages of the solar tower technology are simplicity and scalability, the ability to include a thermal storage, the low thermal capacity (quick start-up) and a high efficiency potential due to high achievable temperatures. To improve the availability and the capacity factor of a solar tower power plant, a hybridization of the plant is considered. In regions with very high irradiation, solar thermal power plants with heat storage facilities can reach a maximum of 3,000 to 4,000 nominal 
load hours per year. Hybridization, with the combustion of biogas, enables the operator to produce electricity day and night for up to 8,600 hours per year. It is expected that such hybrid power plants will have a high potential for the market introduction in the next decade [24]. A hybridisation concept has the advantages of combined cycles, like a high efficiency, and an additional power production by the gas turbine. A further important advantage of hybrid operation compared to solar-only systems lie in high operation time and reduced technical and economical risks. The upgrade of a solar tower power with air receiver technology to a hybrid system by combining it with a gas turbine which uses biogas as fuel is shown in Fig.8.

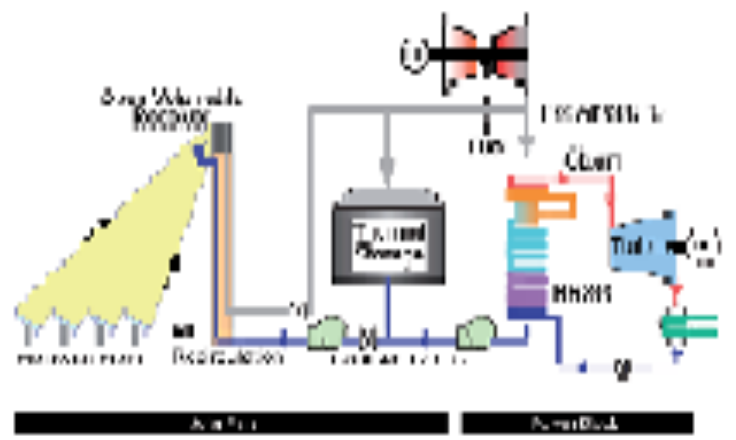

Fig.8: Schematic diagram of a solar tower demonstration plant hybridised with a gas turbine which uses biogas as a burning fuel Source: Solar-Institut Jülich (SIJ)

For the hybridization a gas turbine or a burner is placed in the solar cycle before the heat recovery steam generator (HRSG). The gas turbine is in a parallel position to the receiver and the burner may be located after the solar receiver. This proposed system was the basis for further investigations done by Coelho by using biomass as a fuel [25]. The SOLMASS project aims for the construction of a demonstration power solar tower hybrid solar-biomass plant of $4 \mathrm{MW}$ in Tavira - Algarve. As been pointed out in [26] burning fuel might be also biogas and after the HRSG the exhaust gas is recirculated to the receiver or can be passed to a stack. By using environmentally neutral biogas for operating the gas turbine, the hybrid system is operated to $100 \%$ from renewable energy sources. Such a combination enables the saving of conventional fuels and the recovery of manure and biological waste.On sunny days the air receiver is operated in a solar-only mode. On days with very low direct solar irradiation (very cloudy conditions) the thermal energy provided by the heliostat field is not sufficient for operating the plant. On those days the gas turbine must be operated. The hot exhaust gas from the gas turbine is directed through the heat recovery steam generator (HRSG) for steam generation [27]. Throughout the nights, solely the gas turbine is operated. As described in [24] North Italy was considered as a location with high biogas potential and the described hybrid system of a solar tower with a gas turbine using biogas as a burning fuel was investigated. The biogas considered for this location composed of $56 \%$ methane, $40 \%$ carbon dioxide and other constituents. The selected gas turbine generates a nominal power of $2.7 \mathrm{MWe}$. The hot exhaust gases are directed through a boiler for steam generation. In the steam cycle, the steam is expanded in a steam turbine. The steam turbine and generator of the steam cycle for both locations have a generation capacity of about 1.5 MWe. The results show that a Conventional Combined Power Plant in North Italy generates the estimated energy of about $21 \mathrm{GWh}$ at a fuel consumption of about $12 \mathrm{t}$ of biogas [24].For alternate hybrid operation, locations with high insolation were associated with less fuel consumption and less electricity production. If parallel operation is considered then more electricity production is theoretically expected.

A renewable power plant consisting of such a hybrid solar tower in combination with combustion of biogas in a gas turbine or burner may offer a solution for the treatment of waste from animal manure and agricultural residues in South Europe countries.

\section{References}

1. J. Held, A. Mathiasson, A. Nylander: Biogas from manure and waste products - Swedish case studies. Stockholm, 2008

2. Teodorita Al Seadi, Dominik Rutz, Heinz Prassl, Michael Köttner, Tobias Finsterwalder,

Silke Volk, Rainer Janssen: Biogas handbook Esbjerg, Denmark, October 2008

3. AEBIOM A Biogas Road Map for Europe. October 2009

4. Ceriani, A.: "Le energie alternative e rinnovabili in Lombardia nell'ambito delle attivià produttive", Instituto Regionale di Ricerca Della Lombardia, Milan, January, 2010

5. Swedish energy agency. Production and use of biogas, 2005.

6. Lantz, M., Svensson, M., Björnsson, L., Börjesson, P.: The prospects for an expansion of biogas systems in Sweden: Incentives, barriers and potential, Energy policy, 35:1830-1843, 2007

7. R. Meyer, J. Börner: Bioenerigeträger - eine Chance für die "Dritte Welt" Verfahren - Realisierung Wirkungen. edition sigma, Berlin, 2002
8. R. P. Agrahari, G. N. Tiwari: Parametric study of portable floating type biogas plant. World Renewable Energy Congress, Linköping, Schweden, 2011

9. Bernd Krautkremer, Frank Schünemeyer, Uwe Hoffstede, Dorothee Lensch: Assessment report on testing of packed bed digester and ultrasonic disintegration. Fraunhofer IWES, October 2010

10. Ricahrd A. Zahoransky: Energietechnik.Vieweg, 2007

11. Heinz Schulz, Barbara Eder: Biogas Praxis Grundlagen Planung Anlagenbau Beispiele. ökobuch Verlag, 2001

12. V. K. Sharma, C. Testa, G. Lastella, G. Cornacchia, M. P. Comparato: Inclined-plug-flow type reactor for anaerobic digestion of semi-solid waste. Applied Energy, 65, pp. 173-185, 2000.

13. Chea Eliyan: Anaerobic digestion of municipal solid waste in thermophilic continuous operation. thesis, Thailand, May 2007

14. Biogas - an introduction FNR 2009

15. Anneli Petersson, Arthur Wellinger: Biogas upgrading technologies - developments and innovations. IEA Bioenergy, October 2009 
16. Clare T. Lukehurst, Peter Frost, Teodorita Al Seadi: Utilisation of digestate from biogas plants as biofertiliser. IEA Bioenergy, June 2010

17. M. N. Hansen, T. Birkmose, B. Mortensen, K. Skaaning: 'Miljøeffekter af bioforgasning og separering af gylle'. Grøn Viden, Markbrug, nr. 296, 2004

18. J. Zachary, D. Ugolini: Options for hybrid solar and conventional fossil plants, SolarPACES Symposium, Perpignan, 21-24 September 2010

19. [19] M. Benmarraze, D. Itskhokine, H. Vollberg, S. Benmarraze: Concentrated solar power with biomass hybridization: a fully dispatchable renewable solution, SolarPACES Symposium, Perpignan, 21-24 September 2010

20. D. V. Alonso, F. Rossi, R. G. Falcón, J. L. Carvajal: Thermal analysis and optimization of a hybrid solar biomass power plant, SolarPACES Symposium, Perpignan, 21-24 September 2010

21. J. López-Carvajal, J.A. Vélez-Godino, E. Otero-Cabot: Biomasol hybrid project: solar thermal technology hybridization with biomass combustion in a pilot plan, SolarPACES Symposium, Perpignan, 21-24 September 2010

22. K. Hennecke, P. Schwarzbözl, S. Alexopoulos, J. Göttsche, B. Hoffschmidt, M. Beuter, G. Koll, T. Hartz: Solar Power Tower Jülich The first test and demonstration plant for open volumetric receiver technology in Germany, Proceedings of the 14th
Biennial CSP SolarPACES Symposium, Las Vegas, Nevada, 4-7 March 2008, London.

23. S. Alexopoulos, B. Hoffschmidt, C. Rau: Comparison of steady state and transient simulations for solar tower power plants with open-volumetric receiver. SolarPACES Symposium Proceedings, Granada, Spanien, 20-23 September 2011

24. S. Alexopoulos, B. Hoffschmidt, C. Rau, J. Sattler: Choice of solar share of a hybrid power plant of a central receiver system and a biogas plant in dependency of the geographical latitude World Renewable Energy Congress 2011 - Sweden 8-11 May 2011, Linköping, Sweden

25. B. Coelho, P. Domingues, A. Oliveira, A. Mendes: Solmass project - solar biomass dual hybrid 4 MW CRS pilot plant, SolarPACES Symposium, Perpignan, 21-24 September 2010

26. S. Alexopoulos, B. Hoffschmidt, J. Goettsche, C. Rau, P. Schwarzboezl: First simulation results for the hybridization of small solar power tower plants, Proceedings of 1st International Conference on Solar Heating, Cooling and Buildings, Lisboa, Portugal, 2008.

27. S. Alexopoulos, B. Hoffschmidt, C. Rau, P. Schwarzbözl: Simulation results for a hybridization concept of a small solar tower power plant, SolarPACES Symposium, Berlin, 15-18 September 2009 